INTERNATIONAL JOURNAL
OFEL
PHARMACEUTICAL SCIENCES
RESEARCI

Received on 31 July, 2017; received in revised form, 30 October, 2017; accepted, 27 January, 2018; published 01 May, 2018

\title{
STABILITY INDICATING RP-HPLC METHOD DEVELOPMENT AND VALIDATION FOR SIMULTANEOUS ESTIMATION OF SALBUTAMOL AND BECLOMETHASONE IN BULK AND TABLET DOSAGE FORM
}

\author{
Nandini Abbai * and S. Angala Parameswari \\ Department of Pharmaceutical Analysis, Krishna Teja Pharmacy College, Tirupathi - 517520, Andhra \\ Pradesh, India.
}

Keywords:

Beclomethasone, Salbutamol, Simultaneous estimation RP-HPLC

Correspondence to Author:

Ms. Nandini Abbai

Lecturer,

Department of Pharmaceutical

Analysis, Krishna Teja Pharmacy

College, Chadhalawada Nagar,

Renigunta Road, Tirupati - 517506,

Andhra Pradesh, India.

E-mail: eswarialagusundaram@gmail.com

\begin{abstract}
A new, simple, sensitive, precise, accurate and stability indicating RP-HPLC method has been developed for the simultaneous estimation of salbutamol and beclomethasone in combined tablet dosage form. The analysis was carried out at $230 \mathrm{~nm}$ and this chromatographic separation was achieved with Kromasil $250 \mathrm{C}_{18}[250 \times 4.6 \mathrm{~mm}, 5 \mu]$ column under $25{ }^{\circ} \mathrm{C}$ temperature and using mobile phase water and acetonitrile in a ratio of $55: 45 \mathrm{v} / \mathrm{v}$ adjusted $\mathrm{pH} 2$ with ortho phosphoric acid. The retention times of salbutamol and beclomethasone were found to be $2.030 \pm 0.01 \mathrm{~min}, 3.271 \pm 0.1 \mathrm{~min}$ respectively. The proposed method was validated according to ICH guidelines. The linearity study of salbutamol and beclomethasone was found in concentration range of $25-150 \mu \mathrm{g} / \mathrm{ml}$ and $50-300 \mu \mathrm{g} / \mathrm{ml}$ and correlation coefficient $\left(\mathrm{r}^{2}\right)$ was found to be 0.999 and 0.999 . The percentage recovery was obtained as $98.61 \%$ and $100.75 \% \mathrm{w} / \mathrm{v}$ for beclomethasone and salbutamol. The LOD, LOQ values were obtained from regression equations of beclomethasone and salbutamol were $1.13 \mu \mathrm{g} / \mathrm{ml}, 2.06 \mu \mathrm{g} / \mathrm{ml}$ and $3.42 \mu \mathrm{g} / \mathrm{ml}, 6.23 \mu \mathrm{g} / \mathrm{ml}$ respectively. The studies were carried out by conducting deliberate degradation of the sample with exposure to stress conditions like acidic $(1 \mathrm{M} \mathrm{HCl})$, alkaline $(1 \mathrm{M} \mathrm{NaOH})$, thermal, oxidizing agents $\left(\mathrm{H}_{2} \mathrm{O}_{2}\right)$ and water. This method was validated and met the regulatory requirements for specificity, Linearity, LOD, LOQ, Precision, accuracy and stability for the determination of salbutamol and beclomethasone in bulk and tablet dosage form by RP-HPLC.
\end{abstract}

INTRODUCTION: Salbutamol is chemically 4[2-(tert-butylamino)-1-hydroxyethyl] - 2- (hydroxyl methyl) phenol. It is a short-acting, selective beta2-adrenergic receptor agonist used in the treatment of asthma and COPD. Salbutamol is generally used for acute episodes of bronchospasm caused by bronchial asthma, chronic bronchitis and other chronic broncho pulmonary disorders such as chronic obstructive pulmonary disorder (COPD).

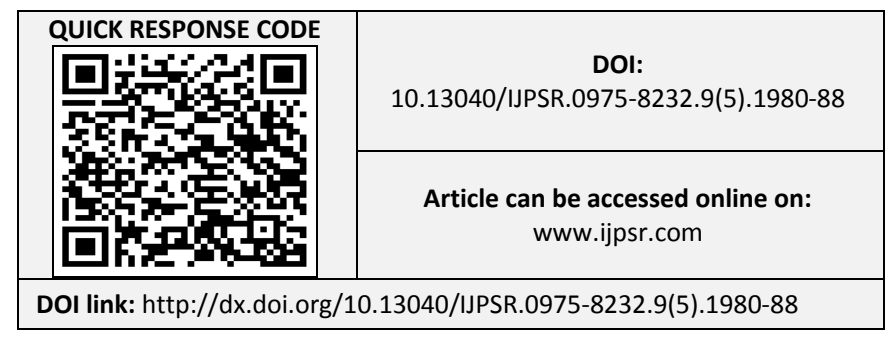

It is also used prophylactically for exercise induced asthma. Beclomethasone is chemically 2-[(1R, 2S,10S,11S,13S,14R,15S,17S)-1-chloro-17 - hydro xy-2,13,15-trimethyl-5-oxo-14-(propanoyloxy) tetra cyclo heptadeca-3,6-dien-14-yl]-2-oxoethyl propanoate. Beclomethasone dipropionate is a prodrug of the free form, it is anti-inflammatory, synthetic corticosteroid and it is used topically as an antiinflammatory agent and in aerosol form for the treatment of asthma and allergic rhinitis. These researches focus the simultaneous estimation of salbutamol and beclomethasone in API or combined tablet form by RP - HPLC.

The extensive literature survey revealed that there were RP-HPLC ${ }^{1-3}$ and UV spectrophotometric ${ }^{4}$, stability indicating RP - HPLC ${ }^{5}$ methods were 
available for the determination of salbutamol and beclomethasone individually or in combination with other drugs ${ }^{6-15}$. But no method was reported for simultaneous estimation of salbutamol and beclomethasone in combined dosage form using RP-HPLC method. The study was thus performed with an aim to develop a simple, economic, sensitive, rapid, accurate and precise method for the determination of salbutamol and beclomethasone in combined tablet dosage form.



FIG. 1: STRUCTURE OF SALBUTAMOL



FIG. 2: STRUCTURE OF BECLOMETHASONE

\section{MATERIALS AND METHODS:}

Chemicals and Reagents: Salbutamol and Beclomethasone were purchased from Spectrum Labs, Hyderabad. Orthophosphoric acid (OPA) purchased from SD Fine Chemicals (Hyderabad, India), methanol, acetonitrile and HPLC grade water were obtained from Rankem. Salbutamol and beclomethasone containing aerotide tablets manufactured by Sun Pharmaceutical Ltd, Hyderabad, India.

Instruments: Waters (2695) HPLC using the software Empower 2. All the glass wares used were 'A' grade.

Standard stock solution: $10 \mathrm{mg}$ of salbutamol and $20 \mathrm{mg}$ of beclomethasone standards were accurately weighed and transferred into a $10 \mathrm{ml}$ clean, dry volumetric flask, $5 \mathrm{ml}$ of diluent was added, sonicated for 5 minutes and made up to the final volume with diluent. $1 \mathrm{ml}$ from the above stock solution was taken into a $10 \mathrm{ml}$ volumetric flask and made up to $10 \mathrm{ml}$ with diluent.
Preparation of Sample Solution: 20 tablets were weighed and crushed. A powder equivalent to 10 $\mathrm{mg}$ of salbutamol and $20 \mathrm{mg}$ of beclomethasone was taken and then transferred into a $10 \mathrm{ml}$ clean, dry volumetric flask, $5 \mathrm{ml}$ of diluents was added, sonicated for 5 minutes and made up to the final volume with diluent. $1 \mathrm{ml}$ of the above stock solution was taken into a $25 \mathrm{ml}$ volumetric flask and made up to $25 \mathrm{ml}$ with diluent.

Chromatographic Conditions: Kromasil $250 \mathrm{C}_{18}$ [250 x $4.6 \mathrm{~mm}, 5 \mu$ ] column was used for the chromatographic separation at a detection wave length of $230 \mathrm{~nm}$, under $25{ }^{\circ} \mathrm{C}$ temperature. Mobile phase of buffer and acetonitrile $\mathrm{pH} 2$ (adjusted with OPA) in a ratio of 55:45 v/v which was degassed under ultra-sonication was selected for elution and same mixture was used in the preparation of standard and sample solutions. Flow rate was optimized to $0.9 \mathrm{ml} / \mathrm{min}$ and the injection volume $10 \mu$ lwas fixed upon the satisfactory results of various system suitability parameters such as retention time, column efficiency, tailing factor, asymmetry of the peaks. The results were shown in Fig. 3.

Method Validation: The RP-HPLC method was validated according to ICH guidelines for validation of analytical procedures for different validation parameters. The method was validated for its specificity, linearity, accuracy, precision, robustness, ruggedness, LOD and LOQ.

System Suitability: System suitability test was carried out to verify that the analytical system was working properly and can give accurate and precise results. The overall system suitability was evaluated for the system suitability of the proposed method. Data from six injections $(10 \mu \mathrm{g} / \mathrm{mL})$ were utilized for calculating parameters like theoretical plates, resolution, tailing factor and \%RSD. The results were shown in Table 2.

Specificity: The specificity studies were carried out by varying specific conditions, i.e., placebo study. A study conducted to demonstrate that diluent and Placebo were not interfering with the analyte peak in the proposed method. Solutions of sample, placebo and blank were prepared individually and chromatograms were obtained. The results were shown in Fig. 3, 4 and 5. 
Accuracy: Accuracy was carried out by \% recovery studies of salbutamol and beclomethasone sat three different concentration levels (50\%, 100 $\%$, and $150 \%$ ). Percentage recovery was calculated from the amount added and the amount recovered. The percentage recovery was within the acceptance criteria, this indicates the accuracy of the method. (Acceptance criteria: \% recovery between 98 102\%). The results were shown in Table 3.

Precision: Precision of an analytical procedure as the closeness of agreement between a series of measurements obtained from multiple sampling of the same homogeneous sample under the prescribed conditions. The results were shown in Table 4.

Linearity: Linearity of an analytical procedure is its ability (within a given range) to obtain test results that are directly proportional to the concentration (amount) of analyte in the samples. The linearity of the method was determined by preparing serial dilutions of minimum 5 concentrations of working stock solutions in the range of $50-300 \mu \mathrm{g} / \mathrm{ml}$ for beclomethasone and 25 - $150 \mu \mathrm{g} / \mathrm{ml}$ for salbutamol. The area of each injection was obtained and the peak area was plotted against actual concentration. The regression coefficient $r^{2}$, $y$-intercept and slope of the regression were calculated.

Limit of Detection and Limit of Quantitation: The LOD is defined as the lowest concentration of an analyte in a sample that can be detected but not quantified. The LOQ is defined as the lowest concentration of an analyte in a sample that can be determined with acceptable precision and accuracy. The LOD and LOQ can be calculated based on the standard deviation of the response and the slope of calibration curve. $\mathrm{LOD}=3.3 \sigma / \mathrm{S} \mathrm{LOQ}=10 \sigma / \mathrm{S}$ where ' $\sigma$ ' is the standard deviation of the intercept of the regression lines and 's' cis the slope of the calibration curve.

Robustness: The robustness of an analytical variation in method parameters such as flow rate, column temperature were varied within a realistic range and the quantitative influence of the variables were determined. The results were shown in Table 5 and Table 6.

Stability Studies: Stability testing was established for estimating the allowed time span between sample collection and sample analysis. It is also important to evaluate an analytical method's ability to measure drug products in the presence of its degradation products. Forced degradation studies typically involve the exposure of samples of the drugs to the relevant stress conditions of acid, base, thermal and UV. The results were shown in Table 7.

Acid Degradation: To $1 \mathrm{ml}$ stock solution of salbutamol and beclomethasone, $1 \mathrm{ml}$ of $2 \mathrm{~N}$ hydrochloric acid was added and refluxed for 30 mins at $60^{\circ} \mathrm{C}$. The resultant solution was diluted to obtain $100 \mu \mathrm{g} / \mathrm{ml}$ and $200 \mu \mathrm{g} / \mathrm{ml}$ solutions and $10 \mu \mathrm{l}$ solutions were injected into the system and the chromatogram were recorded to assess the stability of drug substances. The results were shown in Fig. 9.

Oxidation Degradation: To $1 \mathrm{ml}$ of stock solution of salbutamol and beclomethasone, $1 \mathrm{ml}$ of $20 \%$ hydrogen peroxide $\left(\mathrm{H}_{2} \mathrm{O}_{2}\right)$ was added separately. The solutions were kept for $30 \mathrm{~min}$ at $60^{\circ} \mathrm{C}$. For HPLC study, the resultant solution was diluted to obtain $100 \mu \mathrm{g} / \mathrm{ml}$ and $200 \mu \mathrm{g} / \mathrm{ml}$ solution and $10 \mu \mathrm{l}$ were injected into the system and the chromatograms were recorded to assess the stability of drug substances. The results were shown in Fig. 10.

Alkali Degradation: To $1 \mathrm{ml}$ of stock solution of salbutamol and beclomethasone, $1 \mathrm{ml}$ of $2 \mathrm{~N}$ sodium hydroxide was added separately. The solutions were kept for $30 \mathrm{~min} 60^{\circ} \mathrm{C}$. For HPLC study, the resultant solution was diluted to obtain $100 \mu \mathrm{g} / \mathrm{ml}$ and $200 \mu \mathrm{g} / \mathrm{ml}$ solution and $10 \mu \mathrm{l}$ were injected into the system and the chromatograms were recorded to assess the stability of drug substances. The results were shown in Fig.11.

Thermal Degradation: The standard drug solution was placed in oven at $105{ }^{\circ} \mathrm{C}$ for $6 \mathrm{hr}$ to study dry heat degradation. For HPLC study, the resultant solution was diluted to obtain $100 \mu \mathrm{g} / \mathrm{ml} \&$ $200 \mu \mathrm{g} / \mathrm{ml}$ solution and $10 \mu \mathrm{l}$ were injected into the system and the chromatograms were recorded to assess the stability of drug substances. The results were shown in Fig. 12.

Photo Degradation: The photochemical stability of the drug was also studied by exposing the 1000 $\mu \mathrm{g} / \mathrm{ml}$ and $2000 \mu \mathrm{g} / \mathrm{ml}$ solution to UV light by keeping the beaker in UV Chamber for 7 days or 200 Watt hours $/ \mathrm{m}^{2}$ in photo stability chamber. For HPLC study, the resultant solution was diluted to 
obtain $100 \mu \mathrm{g} / \mathrm{ml}$ and $200 \mu \mathrm{g} / \mathrm{ml}$ solutions and $10 \mu 1$ were injected into the system and the chromatograms were recorded to assess the stability of drug substances. The results were shown in Fig. 13.

RESULTS AND DISCUSSION: Optimization of the method was carried out by performing various trials by change in mobile phase composition, column and flow rate etc. The chromatographic conditions were achieved by water and acetonitrile in a ratio of 55:45 v/v adjusted $\mathrm{pH} 2$ with ortho phosphoric acid was selected as mobile phase and Kromasil $250 \mathrm{C}_{18}[250 \times 4.6 \mathrm{~mm}, 5 \mu]$ column as stationary phase because of better resolution, number of Theoretical plates and symmetric peaks. Salbutamol and beclomethasone were found to show appreciable absorbance at $230 \mathrm{~nm}$ determined spectro-photometrically and hence it was selected as the detection wavelength. Fig. 3 represents chromate-gram of mixture of standard solutions.

TABLE 1: OPTIMIZED CHROMATOGRAPHIC PARAMETERS

\begin{tabular}{cc}
\hline \multicolumn{2}{c}{ Optimized chromatographic conditions } \\
\hline Mode of separation & Isocratic \\
Mobile phase & Water : acetonitrile $(55: 45)$ \\
Column & Kromasil $250 \mathrm{C} 18$ \\
& $(250 \times 4.6 \mathrm{~mm}, 5 \mu)$ \\
Column temperature & $25^{\circ} \mathrm{C}$ \\
Detection wavelength & $230 \mathrm{~nm}$ \\
Run time & $6 \mathrm{~min}$ \\
Injection volume & $10 \mu 1$ \\
Flow rate & $0.9 \mathrm{ml} / \mathrm{min}$ \\
\hline
\end{tabular}

\section{Method Validation:}

System Suitability: An RP -HPLC method was developed by monitoring the system suitability

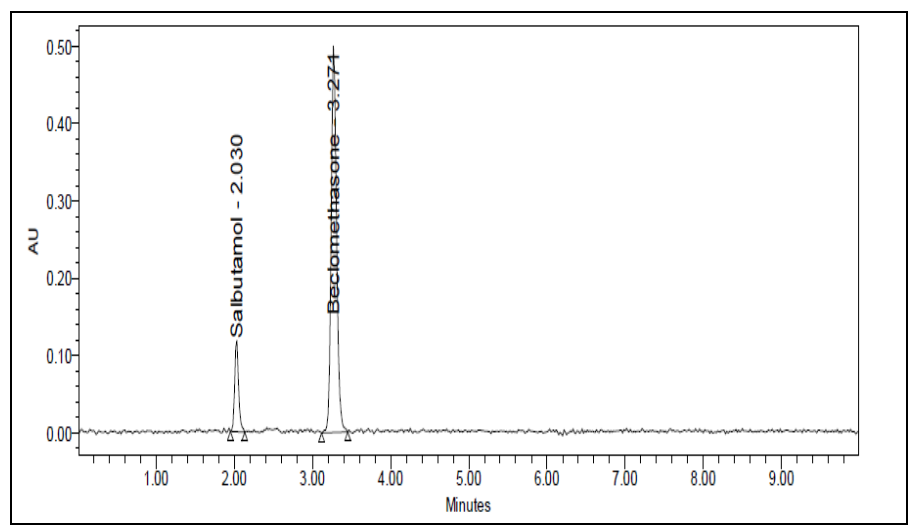

FIG. 3: OPTIMIZED CHROMATOGRAM OF SALBUTAMOL AND BECLOMETHASONE parameters, i.e. Tailing factor (T), the number of theoretical plates $(\mathrm{N})$, the runtime and the cost effectiveness. System suitability method acceptance criteria set in each validation run were: tailing factor $\leq 2.0$ and theoretical plates $>2000$. In all cases, the relative standard deviation (R.S.D) for the analytic peak area for two consecutive injections was $<2.0 \%$. A chromatogram obtained from reference substance solution was presented. System suitability parameters were shown in Table 2. All the system suitability parameters are found to be satisfactory. The peak is reasonably symmetrical. High numbers of theoretical plates indicate the efficient performance of the column with reasonable retention times.

Specificity: The blank chromatogram showed no interference peaks at the retention time of beclomethasone and salbutamol. This indicates that diluent solution used in sample preparation do not interfere in the estimation of beclomethasone and salbutamol. Similarly the placebo sample chromatogram showed no interference peaks at the retention time of beclomethasone and salbutamol respectively, which indicates the specificity of the proposed method. The results were given in Fig. 4, 5 and 6.

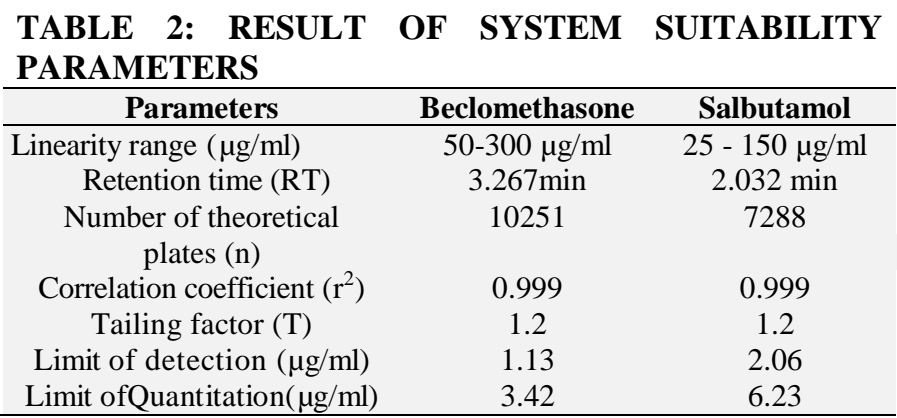

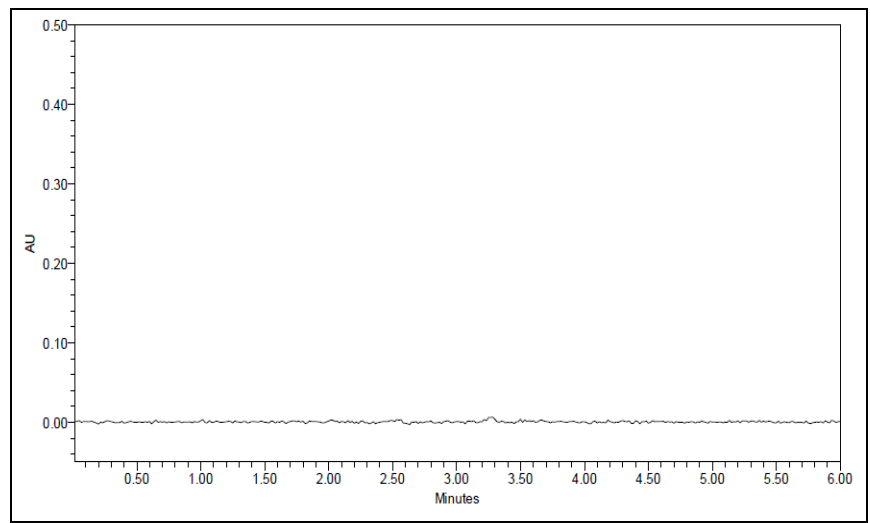

FIG. 4: CHROMATOGRAM OF BLANK 


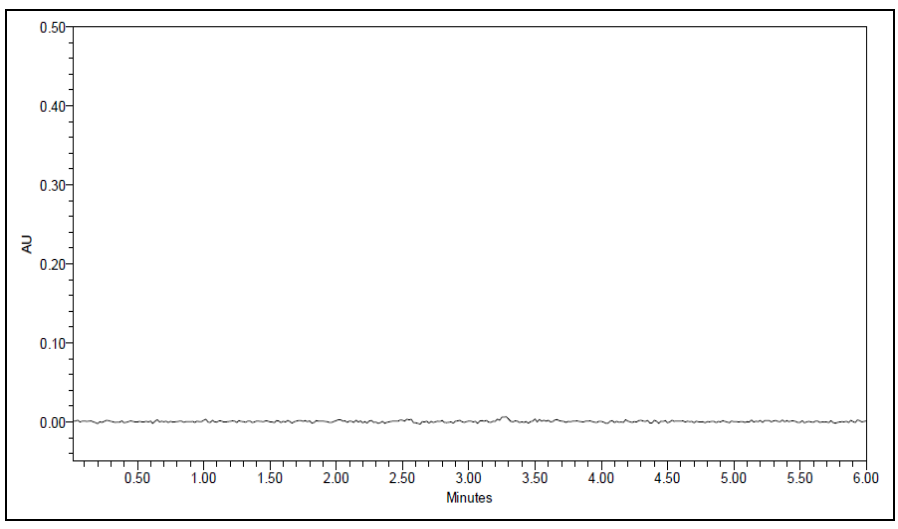

FIG. 5: CHROMATOGRAM OF PLACEBO

The blank and placebo peaks are not interfering with the analyte so the method was specific.

Linearity: The concentration range of 50$300 \mu \mathrm{g} / \mathrm{ml}$ for beclomethasone and $25-150 \mu \mathrm{g} / \mathrm{ml}$ of Salbutamol were found to be linear with correlation coefficients 0.999 and 0.999 for beclomethasone and Salbutamol respectively. The results were given in Fig. 7 and 8.

Accuracy: The accuracy of an analytical method is the closeness of that results obtained by that method to the true value. Accuracy may often be expressed as percent recovery by the assay of known added amount of analyte. \% Recovery

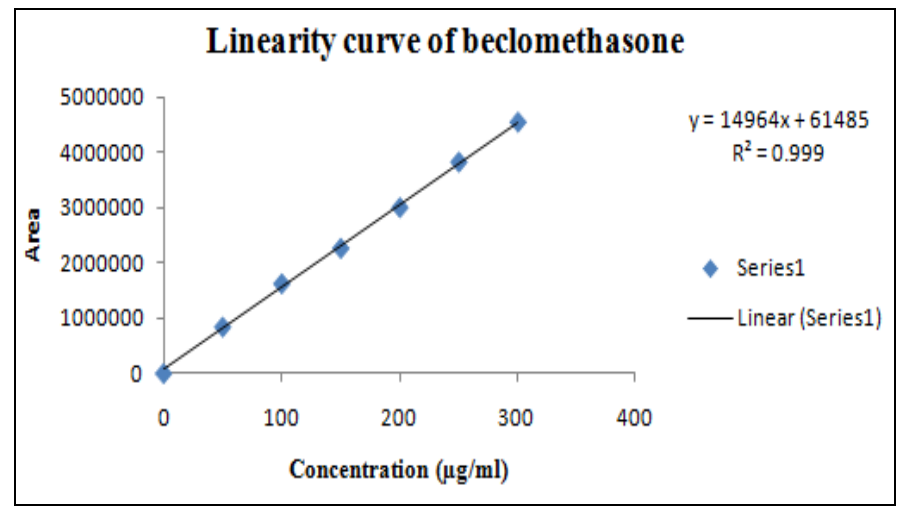

FIG. 7: CALIBRATION PLOT OF BECLOMETHASONE

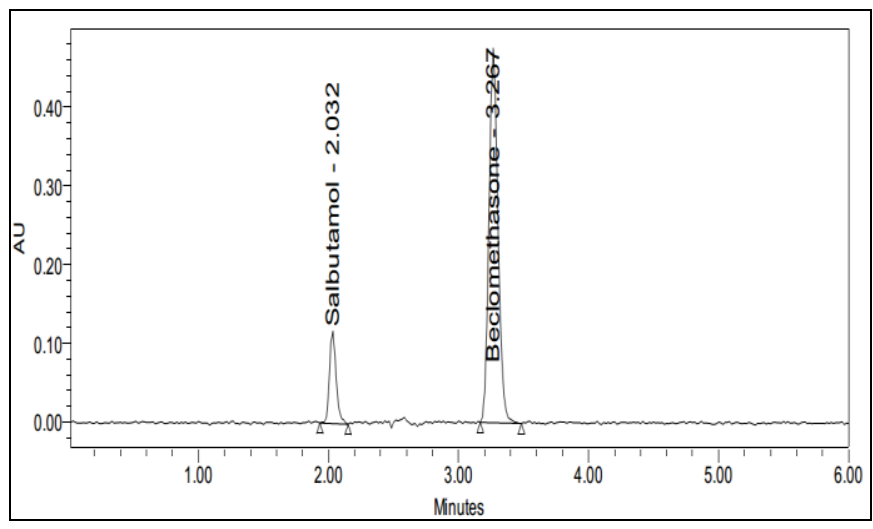

FIG. 6: CHROMATOGRAM OF STANDARD

should be in the range of $98.0 \%$ to $102 \%$. The observed data was within the required range, which indicates good recovery values and hence the method was accurate. The results were shown in Table 3.

Precision: The percentage relative standard deviation was calculated for the peak areas of the drug and it was found to be $0.3 \%$ and $0.7 \%$ for salbutamol and beclomethasone respectively. The $\%$ RSD for the area of six standard injections were should not be more than $2 \%$ and the method was found to be precised. The results were shown in Table 4.

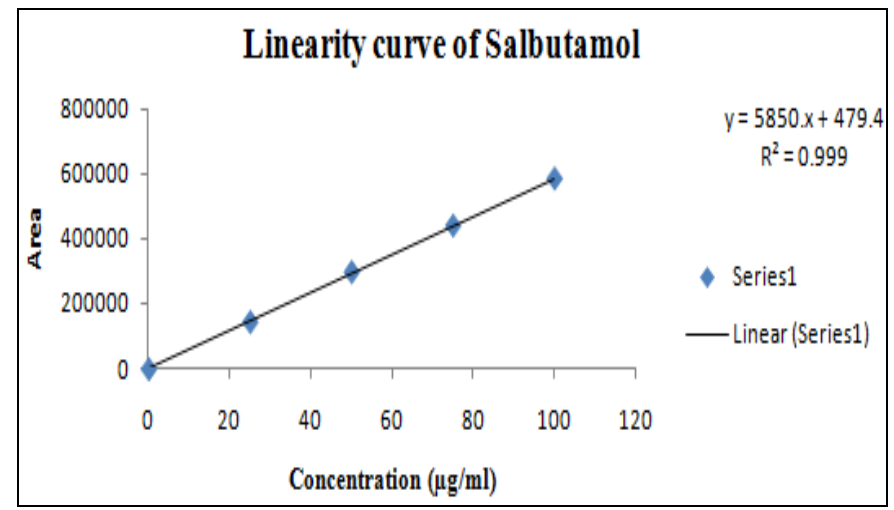

FIG. 8: CALIBRATION PLOT OF SALBUTAMOL

TABLE 3: DATA FOR ACCURACY

\begin{tabular}{ccccc}
\hline Sample & The amount added $(\boldsymbol{\mu g} / \mathbf{m l})$ & Amount recovered $(\boldsymbol{\mu g} / \mathbf{m l})$ & Recovery $(\boldsymbol{\%})$ & \% RSD \\
\hline Beclomethasone & 100 & $99.6 \mu \mathrm{g} / \mathrm{ml}$ & 99.61 & 99.48 \\
& 200 & $198.9 \mu \mathrm{g} / \mathrm{ml}$ & 98.39 & 0.94 \\
Salbutamol & 300 & $295.1 \mu \mathrm{g} / \mathrm{ml}$ & 98.38 & 0.25 \\
& 50 & $49.1 \mu \mathrm{g} / \mathrm{ml}$ & 98.77 & 0.06 \\
& 100 & $98.7 \mu \mathrm{g} / \mathrm{ml}$ & 100.54 & 0.49 \\
\hline
\end{tabular}

TABLE 4: PRECISION RESULTS

\begin{tabular}{ccc}
\hline Analytes & Mean* & \%SD \\
\hline Salbutamol & 0.6 & 0.3 \\
Beclomethasone & 0.7 & 0.7 \\
\hline
\end{tabular}

*six determinations 
Linearity: Linearity of detector response shows the linear relationship between the concentration and the detector response. The coefficient of salbutamol and beclomethasone correlation of was found to be 0.999.The linearity was found in the concentration range of $50-300 \mu \mathrm{g} / \mathrm{ml}$ of beclomethasone, 25 $150 \mu \mathrm{g} / \mathrm{ml}$ of salbutamol.

Regression equation of the beclomethasone and salbutamol are found to be, $\mathrm{y}=14964 \mathrm{x}+61485$, and $y=5778.7 x+3827.3$ and the regression coefficient was 0.999 respectively. The correlation coefficient value was $<1$ shows that the method was linear.

Limit of Detection: Limit of detection of target assay concentration of salbutamol and beclomethasone by using the formula method was found to be $2.06 \mu \mathrm{g} / \mathrm{ml}$ and $1.13 \mu \mathrm{g} / \mathrm{ml}$ respectively.

Limit of Quantification: Limit of quantification of the target assay concentration of salbutamol and beclomethasone by using the formula method was found to be $6.23 \mu \mathrm{g} / \mathrm{ml}$ and $3.42 \mu \mathrm{g} / \mathrm{ml}$ respectively.

Robustness: Robustness of the method tested by keeping the ratio of mobile phase as constant and the chromatograms of drug solution were recorded with different flow rates such as $1.0 \mathrm{ml} / \mathrm{min}, 0.8$ $\mathrm{ml} / \mathrm{min}$ and $0.9 \mathrm{ml} / \mathrm{min}$ and different column temperatures such as $20^{\circ} \mathrm{C}, 25^{\circ} \mathrm{C}, 30^{\circ} \mathrm{C}$. The peak was observed as sharp with good resolution and passes all system suitability parameters indicating the method was robust. The results were reported in Table 5 and 6.

TABLE 5: RESULT OF ROBUSTNESS STUDIES (FOR VARIENT FLOW RATE)

\begin{tabular}{cccc}
\hline Analytes & Flow rate(ml) & Plate count & Tailing \\
\hline Salbutamol & 1.0 & 5840 & 1.26 \\
& 0.9 & 10251 & 1.19 \\
& 0.8 & 6535 & 1.21 \\
Beclomethasone & 1.0 & 8180 & 1.08 \\
& 0.9 & 7197 & 1.10 \\
& 0.8 & 7615 & 1.12 \\
\hline
\end{tabular}

TABLE 6: RESULT OF ROBUSTNESS STUDIES (FOR VARIENT COLUMN TEMPERATURE)

\begin{tabular}{cccc}
\hline Analytes & $\begin{array}{c}\text { Column } \\
\text { temperature }\left({ }^{\circ} \mathbf{C}\right)\end{array}$ & $\begin{array}{c}\text { Plate } \\
\text { count }\end{array}$ & Tailing \\
\hline Salbutamol & 20 & 6695 & 1.22 \\
& 25 & 5834 & 1.24 \\
Beclomethasone & 30 & 5098 & 1.14 \\
& 20 & 7438 & 1.09 \\
& 25 & 7519 & 1.07 \\
& 30 & 7197 & 1.10 \\
\hline
\end{tabular}

Degrdation Studies: The degradation was determined by analyzing both drug solutions in presence of acid, base, hydrogen peroxide, thermal and UV. The results of peak area of salbutamol and beclomethasone was changed hence the drug was degredated but the \% degradation was less than $10 \% \mathrm{w} / \mathrm{v}$. The results were within the limit as per ICH guidelines shown in Table 7.

TABLE 7: FORCED DEGRADATION STUDY RESULTS FOR SALBUTAMOL AND BECLOMETHASONE

\begin{tabular}{ccccccc}
\hline \multirow{2}{*}{$\begin{array}{c}\text { Type of } \\
\text { degradation }\end{array}$} & \multicolumn{3}{c}{ Beclomethasone } & \multicolumn{3}{c}{ Salbutamol } \\
\cline { 2 - 6 } & Area & Recovery in \% & \% Degraded & Area & Recovery in \% & Degraded Drug \% \\
\hline Acid & 2186597 & 95.59 & 4.41 & 380928 & 95.29 & 4.71 \\
Base & 2224596 & 97.3 & 2.75 & 388735 & 97.24 & 2.76 \\
Peroxide & 2249771 & 98.4 & 1.64 & 393297 & 98.38 & 1.62 \\
Thermal & 2267595 & 99.1 & 0.87 & 397025 & 99.32 & 0.68 \\
UV & 2273344 & 99.4 & 0.61 & 396403 & 99.16 & 0.84 \\
Water & 2270637 & 99.3 & 0.73 & 396885 & 99.28 & 0.72 \\
\hline
\end{tabular}



FIG. 9: TYPICAL CHROMATOGRAM OF ACID DEGRADATION OF SALBUTAMOL AND BECLOMETHASONE 


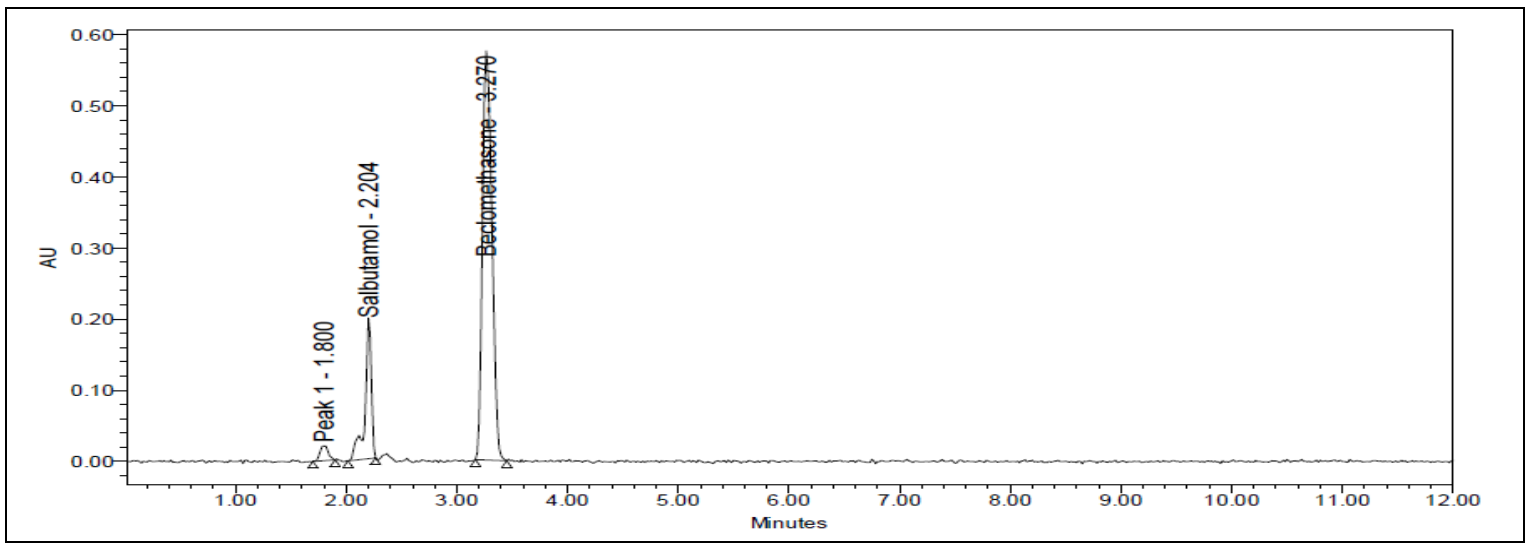

FIG. 10: TYPICAL CHROMATOGRAM OF BASE DEGRADATION OF SALBUTAMOL AND BECLOMETHASONE

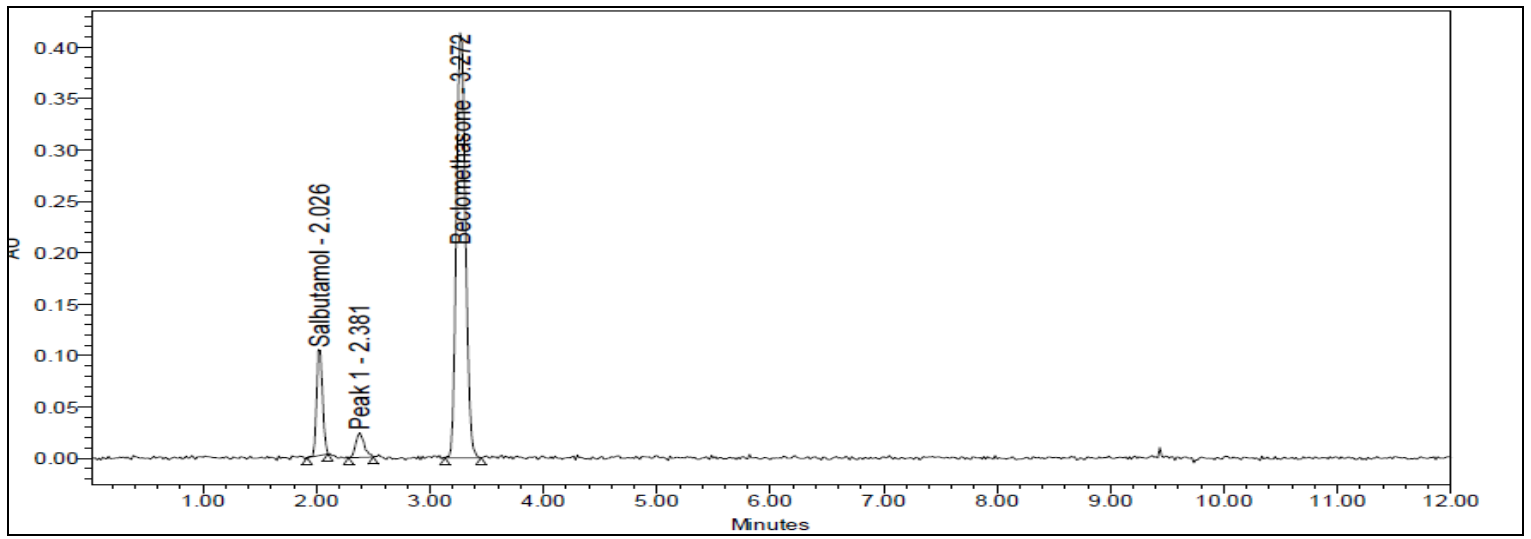

FIG. 11: TYPICAL CHROMATOGRAM OF PEROXIDE DEGRADATION OF SALBUTAMOL AND BECLOMETHASONE

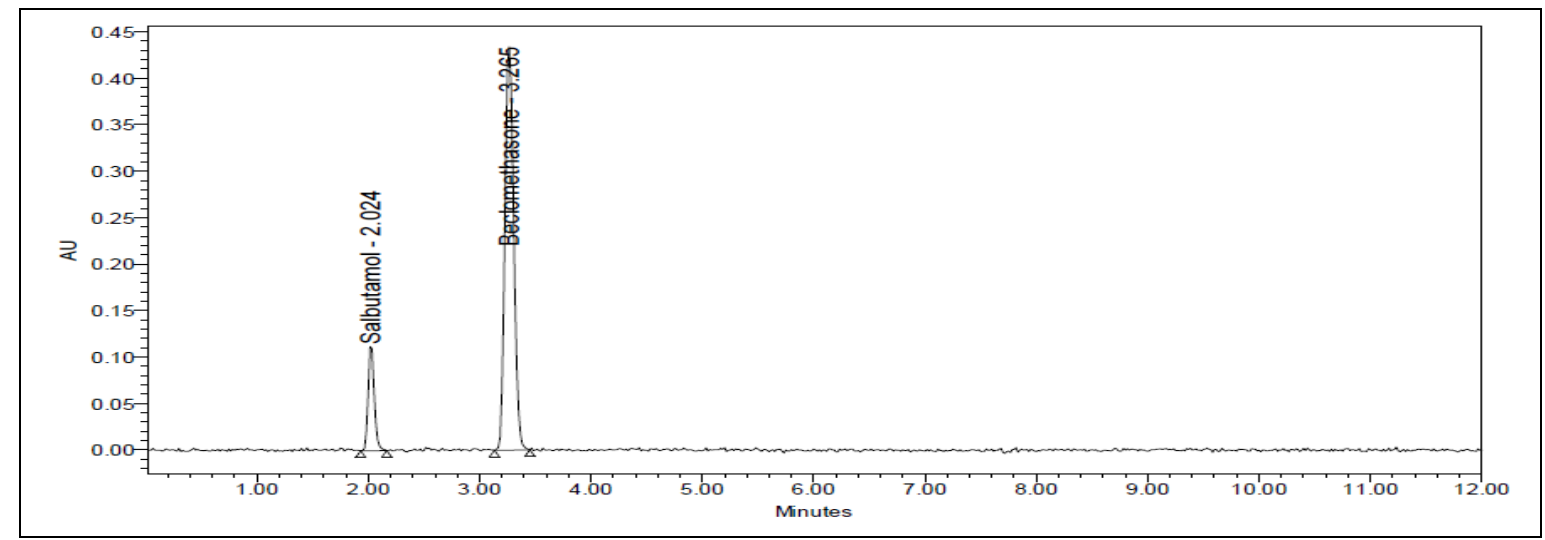

FIG. 12: TYPICAL CHROMATOGRAM OFTHERMAL DEGRADATIONOF SALBUTAMOL AND BECLOMETHASONE

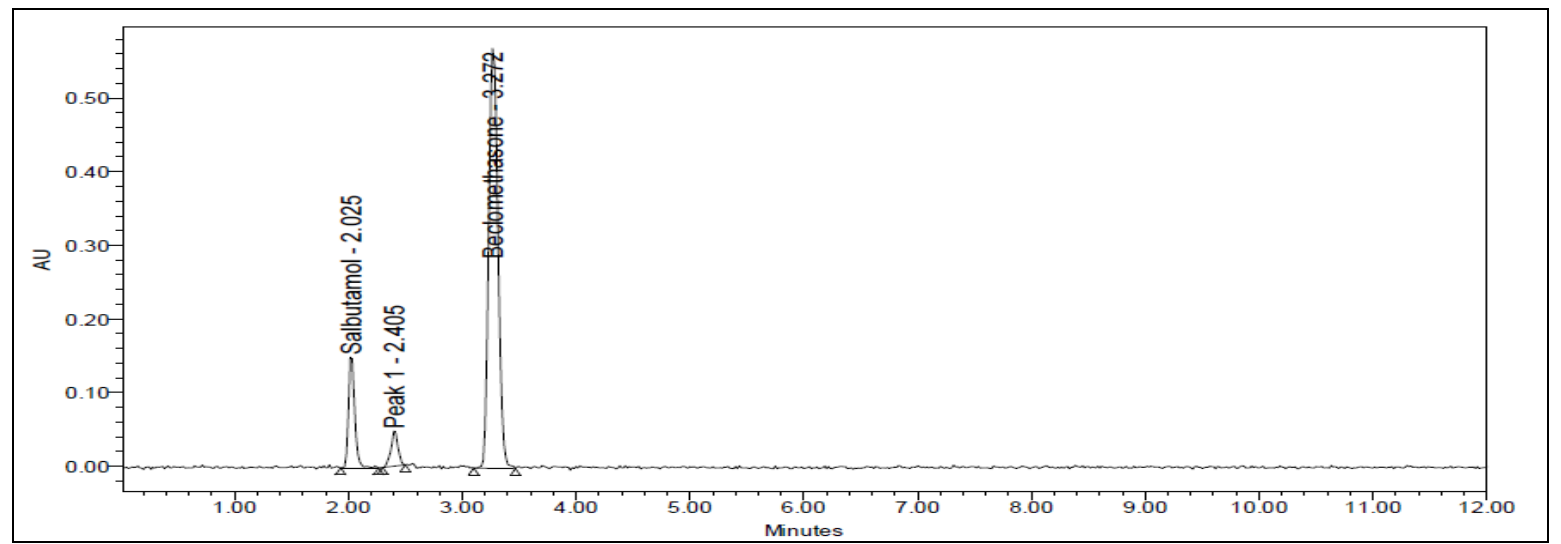

FIG. 13: TYPICAL CHROMATOGRAM OF UV DEGRADATION OF SALBUTAMOL AND BECLOMETHASONE

International Journal of Pharmaceutical Sciences and Research 


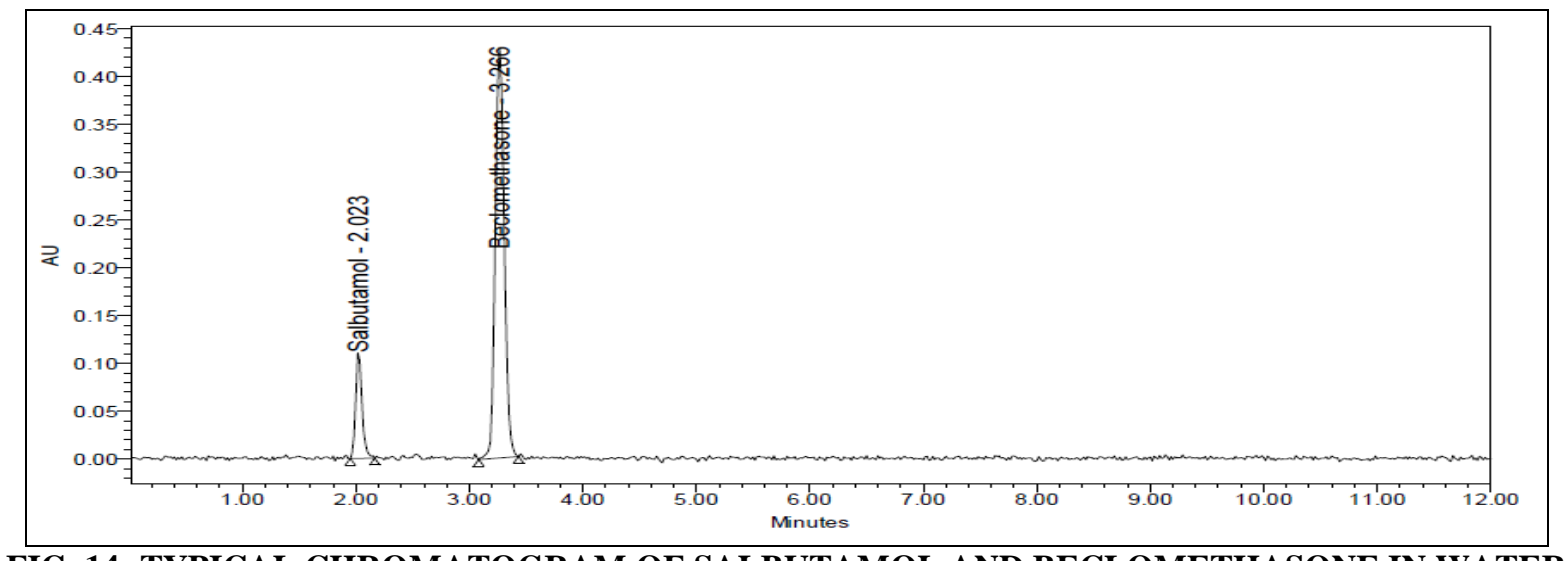

FIG. 14: TYPICAL CHROMATOGRAM OF SALBUTAMOL AND BECLOMETHASONE IN WATER

CONCLUSION: The study was undertaken in order to develop and validate the stability indicating RP-HPLC method for estimation of salbutamol and beclomethasone in pharmaceutical formulations. The method was developed and validated by means of accuracy, precision, linearity, LOD and LOQ and robustness as per ICH guidelines. The results of the study indicate that the proposed RP-HPLC method can be used in quality control departments with respect to routine analysis for the assay of the tablets containing salbutamol and beclomethasone.

ACKNOWLEDGEMENT: Author expresses sincere thanks to the Krishna Teja Pharmacy College for providing facility to carry out this work.

\section{CONFLICTS OF INTEREST: Nil}

\section{REFERENCES:}

1. Amartis E and Gangrade DM: Reverse phase isocratic HPLC method for simultaneous estimation of salbutamol sulphate and beclomethasone dipropionate in rota caps formulation dosage forms. International Journal of Pharmacy and Pharmaceutical Sciences 2011; 3(1): 64-67.

2. Srinivasa RKU: Development and validation of HPLC method for the simultaneous estimation of ketotifen and salbutamol in bulk and dosage form. World Journal of Pharmacy and Pharmaceutical Sciences 2013; 2(6): 61096128.

3. Goyal T: A novel stability indicating HPLC method for simultaneous estimation of guaiphenesin, chlorpheneramine maleate and dextromethorphan $\mathrm{HBr}$. International Journal of Pharmaceutical Sciences and Research 2013; 4(11): 4435-4441.

4. Ivaturi R, Sastry MT and Satyaveni S: Development and validation of stability indicating HPLC method for the determination of lapatinib impurities in bulk and finished formulations. International Journal of Pharmaceutical Sciences and Research 2017; 8(7): 3081-3091.
5. Gandhi SV, Mittal PS and Gaikwa AM: Development and validation of stability indicating RP-HPLC method for simultaneous estimation of beclomethasone dipropionate and salbutamol sulphate. International Journal of Pharmacy and Pharmaceutical Sciences 2015; 7(6): 252257.

6. Gavitre SB, Pingle AP, Kale NR and Mirza JA: RP-HPLC assay method development and validation of beclomethasone dipropionate in metered dose inhalers. Research World Journal of Pharmacy and Pharmaceutical Sciences 2014; 3(8): 2193-2206.

7. Subramanian LS: Simultaneous RP-HPLC estimation of salbutamol, ambroxol and theophylline in Tablets. Asian Journal of Chemistry 2008; 20(6): 4421-4424.

8. Godasu SK and Sreenivas SA: A new validated RP-HPLC method for the determination of metformin HCL and empagliflozin in its bulk and pharmaceutical dosage forms. Int J Pharm Sci Res 2017; 8(5): 2223-32.

9. Pavani P, Srilekha A and Sreedhar B: Stability indicating RP-HPLC method development and validation for simultaneous estimation of glimepiride and ezetimibe in bulk and tablet dosage form. International Journal of Pharmaceutical Sciences and Research 2015; 6(3): 10661077.

10. Rao BV, Vidyadhara S, Nagaraju B and Jhonbi SK: A novel stability indicating RP-HPLC method development and validation for the determination of tenofovir disoproxil fumarate and emtricitabine in bulk and pharmaceutical formulations. International Journal of Pharmaceutical Sciences and Research 2017; 8(5): 2168-2176.

11. Kinjawadekar V, Boddu S and Ghadge O: A novel stability indicating RP-HPLC method for the simultaneous estimation of n-acetylcysteine and ambroxol in combined tablet dosage form. International Journal of Pharmaceutical Sciences and Research 2017; 8(5): 2161-2167.

12. Bulbule M and Gangrade D: Simultaneous estimation of norfloxacin and tinidazole in combined tablet dosage form by using RP-HPLC method. International Journal of Pharmaceutical Sciences and Research 2017; 8(1): 236243.

13. Deorsi D, Gagliardi L, Chimenti F and Tonelli D: HPLC determination of beclomethasone dipropionate and its degradation products in bulk drug and pharmaceutical formulations. International Journal of Pharmaceutical Sciences and Research 1995; 28(9): 1655-1663.

14. Naveen V, Gopinath TB and Kola V: Development and validation of first order derivative method for the simultaneous estimation of sulbutamol sulphate and 
beclomethasone dipropionate. International Journal of Pharmacy and Biological Sciences 2012; 2(1): 83-98.

15. Shinde PR, Patel N, Sahoo B and Chavan S: Assay method development and validation of Salbutamol Sulphate and beclomethasone dipropionate in pressurized metered dose inhaler (MDI). Inventi Rapid Pharmaceutical Analysis \& Quality Assurance 2014; 4: 1-7.

How to cite this article:

Abbai N and Parameswari SA: Stability indicating RP-HPLC method development and validation for simultaneous estimation of salbutamol and beclomethasone in bulk and tablet dosage form. Int J Pharm Sci \& Res 2018; 9(5): 1980-88. doi: 10.13040/IJPSR.0975-8232.9(5).1980-88.

All $\odot 2013$ are reserved by International Journal of Pharmaceutical Sciences and Research. This Journal licensed under a Creative Commons Attribution-NonCommercial-ShareAlike 3.0 Unported License.

This article can be downloaded to ANDROID OS based mobile. Scan QR Code using Code/Bar Scanner from your mobile. (Scanners are available on Google Playstore) 